\title{
AKTUALISASI NILAI-NILAI PANCASILA DALAM PUTUSAN HAKIM ${ }^{1}$
}

\author{
Oleh: \\ Indriati Amarini \\ Fakultas Hukum, Universitas Muhammadiyah Purwokerto \\ E-mail: indriatiamarini@ump.ac.id
}

\begin{abstract}
Abstrak
Pelaku inti yang secara fungsional melaksanakan kekuasaan kehakiman adalah hakim. Tugas hakim dirumuskan paling anggun yaitu alat kekuasaan yang merdeka yang menyelenggarakan peradilan guna menegakkan hukum dan keadilan berdasarkan Pancasila demi terselenggaranya negara hukum Republik Indonesia. Nilai-nilai Pancasila perlu diaktualisasikan dalam putusan hakim. Tulisan ini akan membahas tentang bagaimanakah nilai-nilai Pancasila yang seharusnya termuat dalam putusan-putusan hakim. Indonesia adalah negara hukum berdasarkan Pancasila. Terdapat nilai-nilai dalam Pancasila yang perlu diaktualisasikan dalam putusan hakim yaitu: Ketuhanan yang Maha Esa, keserasian hubungan antara pemerintah dan rakyat berdasarkan asas kerukunan, hubungan fungsional yang proporsional antara kekuasaan-kekuasaan negara, prinsip musyawarah mufakat dan peradilan menjadi sarana mewujudkan keseimbangan antara hak dan kewajiban.
\end{abstract}

Kata kunci: Aktualisasi, Nilai Pancasila, Putusan Hakim

\section{A. PENDAHULUAN}

Sejak awal Indonesia merdeka, bangsa Indonesia menegaskan secara eksplisit ingin membangun suatu tata hukum yang baru. Bangsa Indonesia termasuk negara baru yang menyatakan ketegasan ingin membangun tata hukum yang baru didasarkan landasan kerokhanian Pancasila yang disebut sebagai Sistem Hukum Pancasil. ${ }^{2}$ Sistem Hukum Pancasila adalah sistem hukum milik Bangsa dan Negara Indonesia sendiri, bagian dari warisan peradaban dunia (the product of civilization). Sistem Hukum Pancasila adalah sistem hukum sendiri yang berbeda dengan sistem hukum yang ada di dunia. ${ }^{3}$

Secara material-substansial dan intrinsik, Pancasila bersifat metafisis atau filosofis. Misalnya nilai-nilai dalam sila Ketuhanan Yang Maha Esa, nilai dalam sila Kemanusiaan yang Adil dan Beradab dan seterusnya. Secara praktis fungsional,

1 Artikel ini merupakan bagian dari Disertasi Program Doktor IImu Hukum Universitas Sebelas Maret, Surakarta.

2 Satjipto Rahardjo, 2009, Pendidikan Hukum Sebagai Pendidikan Manusia, Genta Publishing, Yogyakarta, hlm. 118.

3 Teguh Prasetyo, 2016, Sistem Hukum Pancasila Perspektif Teori Keadilan Bermartabat, Nusa Media, Bandung, hlm. 4. 
nilai Pancasila sebagai filsafat hidup atau pandangan hidup dipraktikkan dalam tata budaya masyarakat. Secara formal konstitusional bangsa Indonesia mengakui Pancasila adalah dasar negara (filsafat negara). Secara psikologis dan kultural, bangsa dan budaya Indonesia sederajat dengan bangsa dan budaya manapun. ${ }^{4}$

Pelaku inti yang secara fungsional melaksanakan kekuasaan kehakiman adalah hakim. Tugas hakim adalah menyelenggarakan peradilan guna menegakkan hukum dan keadilan berdasarkan Pancasila demi terselenggaranya negara hukum Republik Indonesia. Berdasarkan hal tersebut, permasalahan dalam penelitian ini adalah bagaimana aktualisasi nilai-nilai Pancasila dalam putusan hakim.

\section{B. METODE PENELITIAN}

Jenis penelitian ini adalah penelitian hukum doktrinal atau penelitian hukum normatif. Hukum, dalam konsep normatif ini, adalah norma baik yang diidentikkan dengan keadilan yang harus diwujudkan (ius constituendum) ataupun norma yang telah terwujudkan sebagai perintah yang eksplisit dan secara positif telah terumus jelas (ius constitutum). Pengumpulan data dilakukan dengan studi kepustakaan untuk mendapatkan data yang berbentuk dokumen dan tulisan melalui penelusuran peraturan perundang-undangan, dokumen, literatur ilmiah, penelitian para ahli. Penelitian ini menggunakan sumber utama data sekunder atau bahan pustaka. Data sekunder meliputi bahan hukum primer, bahan hukum sekunder dan bahan hukum tersier. Jenis data adalah data sekunder yang selanjutnya dianalisis menggunakan logika deduksi.

\section{PEMBAHASAN}

\section{Putusan Hakim Berdasarkan Ketuhanan Yang Maha Esa}

Sebagaimana dikemukakan Padmo Wahyono bahwa lahirnya negara Pancasila berbeda dengan cara pandang liberal yang melihat negara sebagai suatu status tertentu yang dihasilkan oleh suatu perjanjian bermasyarakat dari individu-individu yang bebas atau dari status naturalis ke status civis dengan perlindungan terhadap civil rights, tetapi dalam negara Pancasila terdapat

4 Teguh Prasetyo, 2015, Keadilan Bermartabat Perspektif Teori Hukum, Nusa Media, Bandung, hlm. 78. 
anggapan bahwa manusia dilahirkan dalam hubungannya atau keberadaannya dengan Tuhan Yang Maha Esa. Jalinan hubungan yang istimewa dan erat antara manusia dengan Tuhan Yang Maha Esa, dipertegas dengan penempatan Sila Ketuhanan Yang Maha Esa sebagai sila pertama yang menaungi/melandasi sila kemanusiaan yang adil dan beradab, sila persatuan Indonesia, sila kerakyatan (demokrasi), dan sila keadilan sosial bagi seluruh rakyat Indonesia. ${ }^{5}$

Sistem hukum di Indonesia adalah Pancasila. Bismar Siregar ${ }^{6}$ mengemukakan bahwa sistem hukum dan politik hukum Indonesia adalah Pancasila tidak bisa ditawar-tawar lagi. Hal ini didasari karena undang-undang yang lahir selalu diawali "Dengan Rahmat Tuhan Yang Maha Esa". Kalimat tersebut jangan hanya sebagai formalitas belaka namun harus selalu diamalkan. Oleh karena itu, Pancasila harus tetap menjadi sumber hukum dan Sila Ketuhanan Yang Maha Esa menjadi landasan jiwa setiap kegiatan di bumi Indonesia. Dengan demikian bukan kepastian dan ketertiban hukum yang menjadi kiblat pakar hukum, melainkan keadilan dan kebenaran berdasarkan asma Allah SWT. ${ }^{7}$

Hakim membuat putusan yang berkualitas, pintu masuknya melalui teks dalam hal ini undang-undang atau kodifikasi sebuah regulasi. Namun hal tersebut hanyalah strarting point bagi hukum untuk mengelaborasi suatu perkara sehingga dapat ditempatkan pada konteksnya. Penempatan teks pada konteksnya atau sebaliknya penyandingan konteks dalam teks secara sederhana dalam persidangan disebut sebagai proses pembuktian perkara dengan instrumen alat buktinya. Oleh karena sebuah regulasi hanya sebagai starting point maka kewajiban hakim pada tahap berikutnya adalah menginterpretasikan regulasi tersebut dengan tidak menutup kemungkinan terserapnya nilai-nilai dan aspirasi serta opini yang berkembang dalam masyarakat. The laws in books akan bersinggungan dengan the living law dimana putusan hakim ikut serta menentukan isi dan arah perkembangan hukum Indonesia. Hakim dapat menggali dan menemukan nilai-nilai hukum

\footnotetext{
5 Y.A. Triana Ohiowutun, Menalar Kebebasan Beragama Versi Pancasila, tersedia dihttp://repository.unej.ac.id/handle/123456789/80342

Bismar Siregar, 1995, Hukum Hakim dan Keadilan Tuhan, Gema Insani Press, Jakarta, hlm. 27. Ibid., hlm. 28.
} 
yang baik dan benar sesuai dengan Pancasila dan according to the law of civilized nation....

Sebagaimana diungkapkan James C. Reymond ${ }^{9}$ bahwa teknik membuat putusan yang baik adalah seni "art" bukan sekedar hanya ilmiah "science". Oleh karena seni maka seseorang dapat sepanjang hidupnya mengembangkan dan melalui proses belajar senantiasa mengarah naluri keindahannya. Demikian juga James E. Bond dalam bukunya yang berjudul The Art of Judging yang menyampaikan bahwa : ada dua perbedaan styles of judging antara judicial craftsmen dan judicial statesmen yaitu "Judicial craftsmen look backward for guidance: to the text of the constitution, the original understanding of the text and historical experience. Judicial statesmen look forward: to moral and political ideals and notions of the public good".

Tugas yang diemban oleh aparat penegak hukum sebagaimana dikemukakan oleh Immanuel Kant ${ }^{10}$ merupakan "kewajiban kategoris" atau "kewajiban mutlak" dan tidak mengenal istilah "dengan syarat". Tugas adalah tugas, wajib dilaksanakan. Pelaksanaan tugas hakim adalah dalam rangka "mendistribusikan" keadilan. Hakim melalui penanganan suatu sengketa melaksanakan distribusi keadilan bagi negara atau masyarakat, dan para pihak. Bagi pencari keadilan yang mendambakan keadilan hukum terhadap perkaranya pada hakim maka putusan berkualitas adalah putusan yang dapat mewujudkan keadilan atau putusan yang mencerminkan rasa keadilan yang dapat dilaksanakan dan dapat diterima atau memuaskan pencari keadilan. Sudah seharusnya hakim tidak terbelenggu oleh sekat-sekat formalitas sepanjang demi satu tujuan yaitu Keadilan Berdasarkan Ketuhanan Yang Maha Esa. Irah-irah tersebut mengandung arti bahwa kewajiban menegakkan kebenaran dan keadilan itu wajib dipertanggungjawabkan secara horizontal kepada semua manusia dan secara vertikal dipertanggungjawabkan kepada Tuhan Yang Maha Esa.

8 Jimly Maruli, Dicari: Putusan yang Progresif, Majalah Hukum Varia Peradilan, No. 293 April 21, hlm. 81

9 Menurut Mr. Sutan Muhammad Syah bahwa putusan seorang hakim adalah suatu karya seni atau karya budaya, ibid., hlm. 67.

10 Bernard L. Tanya, 2011, Penegakan Hukum Dalam Terang Etika, ctk. Pertama, Genta Publishing, Yogyakarta, hlm. 25. 
Tujuan hukum adalah semata-mata untuk mencari keadilan. Pengertian keadilan mempunyai banyak makna. Keadilan sebagaimana dikemukakan Bismar Siregar ${ }^{11}$ bukanlah keadilan hukum (undang-undang) melainkan keadilan berdasarkan Ketuhanan Yang Maha Esa. Hal ini dikatakan karena keadilan hukum sifatnya nisbi atau relatif karena buatan manusia yang memiliki keterbatasan, kekurangan dan kelemahan. Selain itu karena: Pertama, keadilan hukum adalah cerminan moral dan perasaan keadilan masyarakat dalam kurun waktu tertentu. Kedua, keadilan hukum adalah cerminan dari kompromi politik dalam masyarakat. Sedangkan keadilan Tuhan bersifat mutlak dan abadi karena merupakan ciptaan Tuhan sendiri. Hakikat keadilan Tuhan Yang Maha Esa adalah keadilan yang dilandasi oleh kebersamaan dalam suasana kasih sayang yaitu keadilan tidak mengenal keberpihakan yang tidak proporsional. Adapun makna keadilan sebagaimana dikutip oleh Harifin A. Tumpa ${ }^{12}$ bahwa menurut Socrates adalah "justice if only was knew what it was". Lord Denning seorang Hakim Agung Inggris menyatakan "All I would suggest is that justice is not somethig you can see. It is not temporal but eternal. How does man know what is justice. It is not the product of his intellect but of his spirit". Sedangkan Clerence Darrow mengungkapan bahwa: "There is no such thing as justice. In fact, the word cannot be defined. Jusice like life, cannot be adequtely defined. Justice is define mist, and is something, inexorable connected to the state of being". Dengan demikian "Justice means diferent things to different people. There is legal justice and moral justice".

Sedangkan konsep keadilan yang dikembangkan John Rawls adalah justice as fairness (keadilan sebagai kejujuran), jadi prinsip keadilan yang paling fair itulah yang harus dipedomani. Menurut John Rawls ${ }^{13}$ ada dua prinsip dasar keadilan yaitu keadilan yang formal dan keadilan yang substantif sebagai berikut.

"The first statement of the two principles reads as follows. First : each person is to have an equal right to the most extensive scheme of equal basic liberties

11 Antonius Sudirman, Op. Cit., hlm. 160.

12 Harifin A. Tumpa, Hukum Keluarga Antara Realita dan Kepastian Hukum, dalam Majalah Hukum Varia Peradilan Tahun XXIV No. 28 September 2009.

13 John Rawls, A Theory Of Justice, The Belknap Press of Harvard University Press Cambridge, Massachusetts, 1971, hlm. 52-53. 
compatible with a similar sheeme of liberties for others. Second : social and economics inequqlities are to be arranged so that they are both (a) reasonaby expected to be everyone's advantage and (b) attached to positions and offices open to all".

\section{Putusan Hakim Yang Berkeadilan Berdasarkan Pancasila}

Keadilan bagi seorang hakim merupakan dasar dalam menetapkan putusan. Bismar Siregar ${ }^{14}$ mengemukakan “... agar mata, hati dan telinga hakim terbuka terhadap berbagai tuntutan yang berkembang dalam masyarakat. Dalam melaksanakan kewajiban, ia tidak hanya berdasarkan hukum tetapi berdasarkan keadilan... Masih banyak hakim yang menjabarkan hukum secara harfiah dan mengabaikan tujuan hukum yang sebenarnya. Tujuan hukum yang sebenarnya tidak harus dirumuskan dalam kata-kata tetapi dapat dipahami dan dihayati karena bersumber pada hati nurani”.

Hal senada dikemukakan Sudikno Mertokusumo ${ }^{15}$ yakni kepastian hukum "rechtssicherheif", kemanfaatan "zweckmassigkeit" dan keadilan "gerechtigkeit". Itu adalah idealnya namun didalam praktiknya jarang terdapat putusan yang mengandung tiga unsur itu secara proporsional. Apabila tidak dapat diusahakan kehadirannya secara proporsional maka paling tidak ketiga faktor itu seyogyanya ada dalam putusan.

Tidak jarang terjadi kepastian hukum bertentangan dengan keadilan. "Hukumnya demikianlah bunyinya, maka harus dijalankan (kepastian hukum)". Tetapi kalau dijalankan dalam keadaan tertentu akan dirasakan tidak adil "lex dura sea tamen ocreta: de wet is wel hard maar het Luid nu eenmaal zo/uu": hukum itu kejam, tetapi demikianlah bunyinya ${ }^{16}$. Adagium dari aliran legisme positivism hukum tersebut, hukum yang hanya mementingkan stukturpengertiannya "begriff des Rechts" tapi menyia-nyiakan cita hukumnya "idée des Rechts" maka sesungguhnya hukum itu akan kehilangan harkat martabat eksistensinya sebagai hukum dan akibat logis lebih lanjut secara

14 Bismar Siregar, 1995, Hukum Hakim dan Keadilan Tuhan, Gema Insani Press, Jakarta, hlm. 35.

15 Sudikno Mertokusumo, Penemuan Hukum Sebuah Pengantar, Yogyakarta, hlm. 79.

16 Ibid. hlm. 80. 
"rechtsfilosofis", hukum itu akan kehilangan tuntutan dan kekuatan mengikatnya sebagaimana pendapat Gustav Radbruch: ${ }^{17}$

"Recht ist wille zur Gerechtigkeit... wenn Gezetze den wille zur Gerechtgkeit bewusstverleugnen, z.B Menschen naoh willkur gewahren und versagen, dann fehlt diesen Gezetzen die Geltung, dann schuld det das volk ihnen keinan gehorsam, dann mussen auch die Juristen de Mut finden, ihnan Rechtskarakter abzusprechen"

Hukum itu adalah hasrat kehendak untuk/demi mengabdi keadilan...apabila hukum/undang-undang secara sadar/sengaja mengingkari keadilan misalnya secara seenaknya dan tidak menentu kepada manusia memberikan tapi sekaligus juga menolak hak-hak asasnya maka undang-undang yang sedemikian itu kehilangan kekuatan berlaku-mengikatnya, karena itu pula rakyat tidak wajib mentaatinya. Oleh karena itu pula maka para ahli/penegak hukum haruslah memiliki keberanian untuk menolak dan menyangkal dan tidak mengakui sifat hukum dari undang-undang tersebut.

Hakim mempunyai peranan mewujudkan total justice ${ }^{18}$ yaitu mendekatkan atau menjembatani keadilan dan kepastian atau legal justice and moral justice yang dalam praktik tidak mudah. Aharon Barak ${ }^{19}$ mengemukakan bahwa hakim yang baik adalah hakim dengan legitimasi yang dimilikinya mampu membuat dan menciptakan hukum lebih dari sekedar hukum yang dapat menjembatani hukum dengan masyarakatnya yaitu "a good judge, is a judge who, within the bounds of the legitimate possibilities at his dispose, makes the law that, more than other law, he is authorized to make, best bridges the gap between law and society and best protect the constitution and its values". Oleh karena itu memerlukan kearifan dengan naluri yang

17 Soejono Koesoemo Sisworo, Beberapa Aspek Filsafat Hukum dalam Penegakan Hukum, Makalah disajikan dalam Diskusi Panel dengan tema: Fungsi dan Tugas Birokrasi dalam Menegakkan Hukum Serta Berbagai Aspek yang Terkait Didalamnya oleh Fakultas Hukum UNDIP hari Selasa, 20 Desember 1988.

18 Cita ideal keadilan yang dikeluarkan pengadilan adalah apa yang digagas oleh Lawrence $\mathrm{M}$. Friedman yaitu Total Justice. Konsep tersebut sekaligus merupakan kritik terhadap sistem pengadilan di Amerika Serikat yang dinilai terlalu banyak pengacara (to many lawyers), terlalu banyak hukum (too much law), dan terlalu banyak perkara di pengadilan (to much litigation), Artidjo Alkostar, Membangun Pengadilan Berarti Membangun Peradaban Bangsa, dalam Varia Peradilan Tahun XX No. 38 Juli 2005.

19 Jimly Maruli, Dicari: Putusan Yang Progresif, dalam Majalah Hukum Varia Peradilan Tahun XXV No. 293 April 2010, hlm. 78. 
tinggi serta hati nurani yang jernih yang dapat diperoleh dengan pengalaman yang cukup, ilmu pengetahuan yang luas disertai kejujuran.

Sebagaimana dikemukakan Mackenzie ${ }^{20}$ bahwa ada beberapa teori atau pendekatan yang dapat digunakan oleh hakim dalam mempertimbangkan penjatuhan putusan dalam suatu perkara, yaitu: Pertama, Teori Keseimbangan yaitu keseimbangan antara syarat-syarat yang ditentukan oleh undang-undang dan kepentingan pihak-pihak yang berkaitan dengan perkara seperti adanya keseimbangan yang berkaitan dengan kepentingan masyarakat, kepentingan penggugat, kepentingan tergugat. Kedua, Teori Pendekatan Seni atau Intuisi. Pendekatan seni dipergunakan oleh hakim dalam penjatuhan suatu putusan lebih ditentukan oleh insting atau intuisi daripada pengetahuan hakim. Ketiga, Teori Pendekatan Keilmuan. Titik tolak teori ini adalah pemikiran bahwa proses penjatuhan putusan harus dilakukan secara sistematis dan penuh kehati-hatian. Pendekatan keilmuan ini merupakan semacam peringatan bahwa dalam memutus suatu sengketa, hakim tidak boleh semata-mata atas dasar intuisi atau insting semata, tetapi harus diengkapi dengan ilmu pengetahuan hukum dan juga wawasan keilmuan hakim dalam menghadapi suatu perkara yang harus diputuskannya. Keempat, Pendekatan pengalaman. Pengalaman dari seorang hakim merupakan hal yang dapat membantunya dalam menghadapi perkara-perkara yang dihadapi sehari-hari, karena dengan pengalaman yang dimilikinya seorang hakim dapat mengetahui bagaimana dampak dari putusan yang dijatuhkan. Kelima, Teori Ratio Decidendi. Teori ini didasarkan pada landasan filsafat yang mendasar yang mempertimbangkan segala aspek yang berkaitan dengan pokok pekara yang disengketakan, kemudian mencari peraturan perundang-undangan yang relevan dengan pokok perkara yang disengketakan sebagai dasar hukum dalam penjatuhan putusan serta pertimbangan hakim harus didasarkan pada motivasi yang jelas untuk menegakkan hukum dan memberikan keadilan bagi para pihak yang bersengketa. Keenam, Teori Kebijaksanaan. Teori ini dapat digunakan oleh

20 Bagir Manan, Hakim dan Pemidanaan, dalam Majalah Hukum Varia Peradilan Edisi No. 249 Bulan Agustus 2006, Ikahi, Jakarta, 2006, hlm. 7. 
hakim agar putusan-putusan yang dijatuhkan dapat memenuhi dimensi keadilan yaitu keadilan formil dan keadilan substantif sekaligus.

\section{Prinsip Mediasi atau Musyawarah dalam Penyelesaian Sengketa}

Dalam mewujudkan tujuan peradilan yang sederhana, cepat dan biaya ringan melalui lembaga pengadilan yang efektif dan efisien maka Mahkamah Agung sebagai penyelenggara peradilan tertinggi di Indonesia mulai menggagas beberapa metode untuk mempersingkat proses penyelesaian sengketa di Pengadilan. Salah satu gagasan tersebut adalahmengoptimalkan lembaga mediasi pada perkara-perkara perdata. Lembaga ini dimaksudkan agar para pihak yang berperkara tidak harus menempuh seluruh tahapan proses persidangan yang panjang dan memakan waktu yang lama namun cukup hanya sampai pada tahap pra-pemeriksaan saja, jika para pihak berhasil mencapai kesepakatan perdamaian melalui mediasi di awal persidangan.

Pengintegrasian mediasi ke dalam proses beracara di pengadilan diharapkan dapat menjadi salah satu instrumen efektif mengatasi masalah penumpukan perkara di pengadilan serta memperkuat dan memaksimalkan fungsi lembaga non-peradilan untuk penyelesaian sengketa di samping proses pengadilan yang bersifat memutus (adjudikasi). Perma Nomor 1 Tahun 2008 tentang Prosedur Mediasi di Pengadilan sebagai penjabaran Pasal 130 HIR/154 Rbg merupakan Perma yang terbaru menggantikan Perma Nomor 2 Tahun 2003. Perma Nomor 1 tahun 2008 merupakan penyempurnaan Perma sebelumnya yang antara lain berisi: (1) adanya kemungkinan para pihak untuk menempuh mediasi di tingkat banding, kasasi maupun PK; (2) adanya kemungkinan kesepakatan damai yang terjadi di luar pengadilan untuk dikuatkan menjadi akta perdamaian dan penambahan batas waktu mediasi menjadi 40 (empat puluh) hari dan bisa diperpanjang selama 14 (empat belas) hari lagi.

Kesepakatan perdamaian akan menjadi penyelesaian yang tuntas karena hasil akhirnya tidak menggunakan prinsip win or lose. Kesepakatan yang telah dikuatkan menjadi akta perdamaian merupakan suatu penyelesaian sengketa yang mengikat dan final. Mengikat karena setiap butirbutir yang disepakati dalam akta perdamaian dapat dilaksanaan melalui 
proses eksekusi (executable) jika salah satu pihak mengingkarinya. Sedangkan final berarti bahwa dengan dikuatkannya kesepakatan para pihak menjadi akta perdamaian telah menutup segala upaya hukum yang tersedia bagi para pihak. Ditinjau dari beberapa segi, penyelesaian dengan proses mediasi banyak memberikan manfaat bagi para pihak. Lebih singkatnya waktu yang ditempuh otomatis akan menekan biaya menjadi sekecil mungkin, sedangkan dari segi emosional, penyelesaian dengan pendekatan win-win solution akan memberikan kenyamanan bagi para pihak, karena butir-butir kesepakatan dibuat sendiri oleh para pihak sesuai dengan kehendaknya.

Sehingga dengan demikian, optimalisasi proses mediasi melalui pengadilan sangatlah penting mengingat tingginya intensitas penggunaan upaya hukum dalam perkara perdata yang mengakibatkan penumpukan perkara di Pengadilan dan Mahkamah Agung. Dalam perkara perdata, para pihak cenderung menggunakan seluruh upaya hukum yang tersedia mulai dari banding, kasasi sampai peninjauan kembali, bahkan banyak perkara yang objek sengketanya sangat kecil sekalipun tetap diajukan sampai ke tingkat peninjauan kembali di Mahkamah Agung.

Mediasi di pengadilan dikonstruksikan dari penafsiran Pasal $130 \mathrm{HIR} /$ 154 Rbg yang berbunyi : "jika pada hari yang ditentukan itu kedua belah pihak menghadap, maka pengadilan negeri dengan perantaraan ketuanya akan mencoba memperdamaikan mereka itu". Pada awalnya Pasal 130 HIR/ 154 Rbg tersebut hanya diterapkan sebatas memberikan ruang kepada para pihak untuk menempuh perdamaian sendiri, sedangkan hakim yang menyidangkan tidak dapat terlalu jauh masuk kedalam persoalan para pihak karena terbentur dengan aturan kode etik dan hukum acara sehingga para pihak sendiri yang harus aktif untuk menempuh perdamaian itu.

Menurut ketentuan Pasal 1 angka 10 Undang-undang Nomor 30 Tahun 1999 tentang Arbitrase dan Alternatif Penyelesaian Sengketa menyebutkan: "alternatif penyelesaian sengketa adalah lembaga penyelesaian sengketa atau beda pendapat melalui prosedur yang disepakati para pihak yakni penyelesaian di luar pengadilan dengan cara konsultasi, negosiasi, mediasi, konsiliasi atau penilaian ahli. Pada umumnya pengertian mediasi merupakan proses penyelesaian sengketa di luar pengadilan sebagaimana dikemukakan 
oleh para sarjana tentang definisi mediasi, sedangkan judul dari Perma Nomor 1 Tahun 2008 adalah Prosedur Mediasi di Pengadilan yang artinya suatu proses yang ada dalam kekuasaan dan kewenangan pengadilan. ${ }^{21}$

Sebagai perbandingan, akan penulis uraikan proses mediasi (chotei) dan proses perdamaian (wakai) melalui pengadilan di Jepang. Wakai (upaya perdamaian dalam proses persidangan) maupun chotei (mediasi untuk mencapai kesepakatan antara pihak-pihak yang bersengketa di luar proses persidangan) banyak digunakan dalam penyelesaian perkara pada lingkungan peradilan di Jepang baik di lingkungan peradilan tingkat pertama, banding bahkan di tingkat kasasi dalam perkara perdata. Antara wakai dan chotei keduanya memiliki kesamaan dalam hal mencari penyelesaian sengketa yang layak melalui kesepakatan diantara para pihak dengan damai.

Negara Jerman juga menerapkan dan menggunakan istilah Court Connected Mediation dengan schlichtung. Ada perbedaan antara model di Jepang dan Jerman adalah :“... The Japanese model is based on the pursuit for social harmony, moral, duties and other extra-legal considerations." Sedangkan di Jerman : The German approach, as embodied in the Bavarian Mediation Law, stands in harsh contrast to the Japanese recognition of extralegal consideration..."

Sistem sebagaimana dianut negara Jepang dan Jerman, juga dipakai negara Swedia dan Australia. Perbedaan masing-masing didasarkan pada sistem hukum negara masing-masing. Sebagaimana tertulis: The national systems show great diversity, however. From the passive trial judge and referral out of the court in Australia to the very active trial judge and statutory conciliation in Japan wiyth the Swedish system being positioned somewhere in-between. ${ }^{22}$

4. Pengadilan Menjadi Sarana Mewujudkan Keseimbangan Antara Hak dan Kewajiban

21 Darmoko Yuti Witanto, 2010, Beberapa Permasalahan dalam Perma Nomor 1 Tahun 2008 tentang Mediasi di Pengadilan, Varia Peradilan No. 294.

22 E Ficks, 2015, E Ficks, "Models of General Court-Conneted Conciliation and Mediation for Commercial Disputes in Sweeden, Australia and Japan", tersedia dalam sydney.edu.au/law/.../Z.JapanR25_09_Ficks.pdf . 
Hakim ${ }^{23}$ memiliki peran yang sentral dalam proses peradilan. Strategisnya posisi hakim dalam lembaga pengadilan, Ronald Dworkin menyatakan "judges are its princes of law's empire"24. Menurut J.P. Dawson, hakim merupakan anggota masyarakat setempat yang terkemuka dan terhormat. Bahkan JR Spencer menyebutkan putusan yang dijatuhkan pengadilan diibaratkan seperti putusan Tuhan atau "the judgement was that of God". ${ }^{25}$ Pernyataan senada juga diungkapkan Stewart Macaulay, et.all. bahwa "The judge is a more ubiquitous figure in legal history than the lawyer or any other legal professional". 26

Kedudukan hakim menjadi sangat strategis, urgent serta mulia dikarenakan hakim mengemban amanat sebagai "Penyambung Titah Allah S.W.T. dan Rasul Nya di muka bumi” dan juga menggali nilai-nilai yang hidup di tengah-tengah masyarakat. Dalam kerangka yang demikian itu, maka peran hakim menjadi strategis, hakim tidak hanya mengerjakan pekerjaan rutin memutus perkara, tetapi juga senantiasa melakukan "refleksi teoritis" dan "abstraksi empiris" secara terus menerus sehingga dapat melahirkan "ijtihad" yang inovatif dalam pembangunan hukum. ${ }^{27}$

Menurut Asikin Kusumahatmadja ${ }^{28}$ bahwa setiap teks hukum dipastikan mempunyai cita-cita hukum "wasiat wajibah" yang pernah diwasiatkan oleh para pendahulu pendiri negara Republik Indonesia yang tersimpan dalam Pembukaan Undang-Undang Dasar 1945 yang di dalamnya terkandung silasila dalam Pancasila sebagai ideologi negara dan bangsa, penuntun hidup berbangsa dan bernegara dalam membaca teks hukum dan simbol-simbol negara. Sebagaimana pesan Asikin Kusumahatmadja yang ditujukan kepada hakim bahwa hukum jangan dipandang sebagai kaidah formal semata, karena

23 M. Fauzan, Filsafat Hermeneutika Sebagai Metode Penemuan Hukum Yurisprudensi”, Varia Peradilan No. 290, Januari 2010, hlm. 38

24 Ronald Dworkin, Law's Empire, Harvard University Press, Cambridge Massachusetts, 1986.

25 Adi Sulistiyono, Pengembangan Kemampuan Hakim dari Perspektif Sosiologis, Makalah disampaikan dalam Lokakarya Pengembangan Kemampuan Hakim, Kerjasama Komisi Yudisial, Pengadilan Tinggi, Fakultas Hukum Universitas Sam Ratulangi, tanggal 21-22 Oktober di Hotel Ritzy Manado, hlm. 1

26 Stewart Macaulay, Lawrence M. Friedman et.all, 2007, Law in Action A Socio Legal Reader, Foundation Press, United States of America, hlm. 729.

27 Awaludin, Hakim Yang Ideal Menurut Kacamata Islam, Varia Peradilan No. 314 Januari 2012, hlm. 90.

28 M. Fauzan, Pesan Keadilan di Balik Teks Hukum yang Terlupakan (Refleksi atas Kegelisahan Prof. Asikin), Varia Peradilan No. 299 Oktober 2010, hlm. 34. 
hukum adalah ciptaan manusia yang sangat terbatas wawasan, pengetahuan dan jangkauannya sehingga pada suatu saat kaidah formal yang mati tersebut, sehingga berhati nurani dan dapat memberikan manfaat penyelesaian yang adil dalam kasus konkrit dalam masyarakat. Hakim harus dapat memberi hidup dan menghidupkan kaidah formal.

Artidjo Alkostar ${ }^{29}$ mengemukakan bahwa hukum sejatinya mengandung pesan suara yang mencakup nilai-nilai ideologis, logis, etis dan estetis yang diwujudkan dalam ketentuan formal sebagai bagian suara atau pesan nilainilai tersebut. Selain itu hukum harus mempertimbangkan faktor-faktor faktual yang secara realistik turut menentukan terbentuknya opini dan persepsi. Oleh karena itu, hukum formal harus diisi dengan menyesuaikan dinamisasi perkembangan nilai-nilai dan faktor-faktor kekuatan di sekitar masyarakat setempat. Hukum yang mencakup pengertian undang-undang memiliki hubungan sentrifugal (bergerak ke luar) dengan faktor sosial, ekonomi, politik dan budaya. Hukum juga memiliki hubungan sentripetal (bergerak ke dalam) dengan nilai logis (kebenaran), etis (keadilan) dan estetis (keindahan). Hukum dalam tekstur (susunan) tersebut tidak hanya bersifat yuridis formal dan tidak seperti peti kemas kosong "empty container" tetapi hukum tersebut memiliki spirit nilai-nilai kehidupan komunitas manusia. Selanjutnya Asikin ${ }^{30}$ menganjurkan kepada para hakim agar menguasai penafsiran hukum untuk memberi hidup teks hukum yang mati terutama teks hukum yang ditinggalkan oleh kolonial seperti hukum perdata, hukum pidana dan lain-lain.

\section{SIMPULAN}

Indonesia adalah negara hukum yang berlandaskan nilai-nilai Pancasila. Sistem Hukum di Indonesia adalah Pancasila. Pelaku inti yang secara fungsional melaksanakan kekuasaan kehakiman adalah hakim. Tugas hakim adalah menyelenggarakan peradilan guna menegakkan hukum dan keadilan berdasarkan Pancasila demi terselenggaranya negara hukum Republik Indonesia. Nilai-nilai Pancasila yang seyogyanya diaktualisasikan dalam putusan hakim antara lain: nilai-nilai Ketuhanan Yang Maha Esa, nilai-nilai keadilan, keserasian hubungan

29 Ibid., hlm. 38.

30 lbid. hlm. 42. 
antara pemerintah dan rakyat berdasarkan asas kerukunan, hubungan fungsional yang proporsional antara kekuasaan-kekuasaan negara, prinsip mediasi atau musyawarah dalam penyelesaian sengketa dan peradilan menjadi sarana mewujudkan keseimbangan antara hak dan kewajiban.

\section{DAFTAR PUSTAKA}

\section{Buku}

Dworkin, Ronald, 1986, Law's Empire, Harvard University Press, Cambridge Massachusetts.

Macaulay, Stewart, Friedman, Lawrence M. et.all, 2007, Law in Action A Socio Legal Reader, Foundation Press, United States of America.

Mertokusumo, Sudikno, 2014, Penemuan Hukum Sebuah Pengantar, Yogyakarta,

Prasetyo, Teguh, 2016, Sistem Hukum Pancasila Perspektif Teori Keadilan Bermartabat, Nusa Media, Bandung.

2015, Keadilan Bermartabat Perspektif Teori Hukum, Nusa Media, Bandung.

Rahardjo, Satjipto, 2009, Pendidikan Hukum Sebagai Pendidikan Manusia, Genta Publishing, Yogyakarta.

Rawls, John, 1971, A Theory Of Justice, The Belknap Press of Harvard University Press, Cambridge Massachusetts.

Siregar, Bismar, 1995, Hukum Hakim dan Keadilan Tuhan, Gema Insani Press, Jakarta.

Sudirman, Antonius, 2007, Hati Nurani Hakim dan Putusannya Suatu Pendekatan dari Perspektif IImu Hukum Perilaku (Behavioral Jurisprudence Kasus Hakim Bismar Siregar, Citra Aditya Bakti, Bandung.

Tanya, Bernard L., 2011, Penegakan Hukum dalam Terang Etika. ctk. Pertama. Genta Publishing, Yogyakarta.

\section{Perundang-undangan}

Undang-undang Nomor 30 Tahun 1999 tentang Arbitrase dan Alternatif Penyelesaian Sengketa.

Undang-undang Nomor 48 Tahun 2009 tentang Kekuasaan Kehakiman.

Perma Nomor 1 Tahun 2008 tentang Prosedur Mediasi di Pengadilan 


\section{Sumber Lain}

Alkostar, Artidjo, Membangun Pengadilan Berarti Membangun Peradaban Bangsa, Varia Peradilan Tahun XX No. 38, Juli 2005.

Awaludin, Hakim Yang Ideal Menurut Kacamata Islam, Varia Peradilan No. 314 Januari 2012.

Fauzan, M., Filsafat Hermeneutika Sebagai Metode Penemuan Hukum Yurisprudensi”, Varia Peradilan No. 290, Januari 2010.

Pesan Keadilan di Balik Teks Hukum yang Terlupakan (Refleksi atas Kegelisahan Prof. Asikin), Varia Peradilan No. 299, Oktober 2010.

Ficks, E., 2015, Models of General Court-Conneted Conciliation and Mediation for Commercial Disputes in Sweeden, Australia and Japan, Tersedia dalam sydney.edu.au/law/.../Z.JapanR25_09_Ficks.pdf.

Manan, Bagir, Hakim dan Pemidanaan, dalam Majalah Hukum Varia Peradilan Edisi No. 249, Bulan Agustus 2006.

Maruli, Jimly, Dicari: Putusan Yang Progresif, dalam Majalah Hukum Varia Peradilan Tahun XXV No. 293, April 2010.

Ohiowutun, Y.A. Triana, Menalar Kebebasan Beragama Versi Pancasila, tersedia dihttp://repository.unej.ac.id/handle/123456789/80342

Sisworo, Soejono Koesoemo, Beberapa Aspek Filsafat Hukum Dalam Penegakan Hukum, Makalah disajikan dalam Diskusi Panel dengan tema : Fungsi dan Tugas Birokrasi dalam Menegakkan Hukum Serta Berbagai Aspek yang Terkait Didalamnya oleh Fakultas Hukum UNDIP hari Selasa, 20 Desember 1988.

Sulistiyono, Adi, Pengembangan Kemampuan Hakim dari Perspektif Sosiologis, Makalah disampaikan dalam Lokakarya Pengembangan Kemampuan Hakim, Kerjasama Komisi Yudisial, Pengadilan Tinggi, Fakultas Hukum Universitas Sam Ratulangi, tanggal 21-22 Oktober di Hotel Ritzy Manado.

Tumpa, Harifin A., Hukum Keluarga Antara Realita dan Kepastian Hukum, dalam Majalah Hukum Varia Peradilan Tahun XXIV No. 28, September 2009.

Witanto, Darmoko Yuti, Beberapa Permasalahan dalam Perma Nomor 1 Tahun 2008 tentang Mediasi di Pengadilan, Varia Peradilan No. 294, Mei 2010. 